\title{
FACTORS ASSOCIATED WITH SERVICE PERFORMANCE AMONG COMMUNITY HEALTH CENTER EMPLOYEES IN KARANGANYAR, CENTRAL JAVA
}

\author{
Mujiran'), Setyo Sri Rahardjo ${ }^{3}$, Bhisma Murti²) \\ 1)District Health Office, Karanganyar, Central Java \\ ${ }^{2)}$ Masters Program in Public Health, Universitas Sebelas Maret \\ ${ }^{3}$ Faculty of Medicine, Universitas Sebelas Maret
}

\begin{abstract}
Background: Based on the strategic plan of the Karanganyar Health Office, the good accreditation and performance assessment of community health center have not yet been achieved. This is inseparable from the performance of the employee service per-formance. This study aimed to determine factors associated with service performance among community health center employees in Karanganyar, Central Java.

Subjects and Method: A cross-sectional study was carried out in 21 community health centers, Karanganyar, Central Java, in October-November. A sample of 210 employees in community health worker was selected by simple random sampling. The dependent variable was service performance. The independent variables were age, edu-cation, tenure, incentive, motivation, skill, satisfaction, accreditation status of commu-nity health center, and working environment. The data were collected by question-naire. The data were analyzed by a multiple logistic regression.

Results: Service performance increased with age $\geq 38$ years $(b=1.09 ; 95 \% \mathrm{CI}=0.19$ to 1.99; $\mathrm{p}=0.018)$, education $\geq$ diploma $3(\mathrm{~b}=-0.40 ; 95 \% \mathrm{CI}=-1.67$ to $0.87 ; \mathrm{p}=0.535)$, tenure $\geq 3$ years $(b=-0.71 ; 95 \% C I=-1.79$ to $0.37 ; p=0.199)$, good incentive $(b=0.96 ; 95 \% C I=-0.28$ to 2.19 ; $\mathrm{p}=0.128)$, good motivation $(\mathrm{b}=0.93 ; 95 \% \mathrm{CI}=0.09$ to $1.77 ; \mathrm{p}=0.030)$, good skill $(\mathrm{b}=0.97$; $95 \% \mathrm{CI}=0.06$ to $1.88 ; \mathrm{p}=0.037)$, satisfied $(\mathrm{b}=0.92 ; 95 \% \mathrm{CI}=0.05$ to $1.78 ; \mathrm{p}=0.037)$, and good working environment $(b=0.95 ; 95 \% \mathrm{CI}=0.11$ to $1.80 ; \mathrm{p}=0.026)$.

Conclusion: Service performance in community health center employees increases with age $\geq 38$ years, $\geq$ diploma, $\geq 3$ years of service, good incentive, good motivation, good skill, satisfied, and good working environment.
\end{abstract}

Keywords: service performance, employee, community health center

\section{Correspondence:}

Mujiran. Masters Program in Public Health, Universitas Sebelas Maret, Jl. Ir. Sutami 36 A, Surakarta 57126, Central Java, Indonesia. Email: mujiransismiharjo@gmail.-com. Mobile: +62 812-2603-915.

The $7^{\text {th }}$ International Conference on Public Health Solo, Indonesia, November 18-19, 2020| 356 https://doi.org/10.26911/the7thicph.04.41 